\title{
Linking Environmental Water Scarcity and Options for Adaptation in the MENA Region
}

\section{Bachar Ibrahim, Henry Mensah}

Faculty of Economy, Law and Society, Department of Public Law with Reference to the Law of Environment and Planning, Brandenburg University of Technology Cottbus-Senftenberg, Cottbus, Germany Email: Bachar.Ibrahim@b-tu.de, Mensahen@b-tu.de

How to cite this paper: Ibrahim, B. and Mensah, H. (2017) Linking Environmental Water Scarcity and Options for Adaptation in the MENA Region. Journal of Water Resource and Protection, 9, 378-392. https://doi.org/10.4236/jwarp.2017.94025

Received: February 11, 2017

Accepted: March 26, 2017

Published: March 29, 2017

Copyright ( 92017 by authors and Scientific Research Publishing Inc. This work is licensed under the Creative Commons Attribution International License (CC BY 4.0).

http://creativecommons.org/licenses/by/4.0/

cc) (i) Open Access

\begin{abstract}
Contamination of surface and underground water by sea level rise, surface runoff, and land use activities such as industrial and agricultural activities can lead to water scarcity. Water could be available and accessible but not suitable for human use. In the Middle East and North Africa (MENA) region countries, the agriculture sector depends massively on water for farming activities, which consumes about $80 \%$ of the available water resources. In this context, the issue of environmental water scarcity is under highlighted, though the use of this term itself is still lacking in an international context (FAO). Meanwhile, the international goal of universal access to clean freshwater is included in global development targets (SDGs). This study provides some insights and deepens our understanding on environmental water scarcity, particularly MENA region countries. This review paper begins with an introduction to water scarcity and continues with a discussion of environmental issues associated with water scarcity in MENA region countries. Finally, we suggest some adaptive measures in two distinct areas such as agriculture sectors and policy makers and conclude that the lack of implementation of this particular term is hindering sustainable development in MENA region countries.
\end{abstract}

\section{Keywords}

Adaptation, MENA, Climate Change, Water Scarcity, Water Quality, Environment

\section{Introduction}

Water use has been growing globally as the population and economies' economic growth. The United Nations [1] estimates that by 2025, countries experiencing absolute water scarcity are most likely to be 1.800 million people with less than $500 \mathrm{~m}^{3}$ of the available water per person per year. In addition, FAO explains that 
two-thirds of the world population could be affected by water shortage which is estimated to be between 500 and $1000 \mathrm{~m}^{3}$ of available water per person per year. The shortage of water could be worsened because of population growth and infrastructural development which can put stress on less available water resources.

MENA region countries include Algeria, Bahrain, Djibouti, Egypt, Iran, Iraq, Israel, Jordan, Kuwait, Lebanon, Libya, Morocco, Oman, Qatar, Saudi Arabia, Syrian, Tunisia, United Arab Emirates, Yemen and West bank and Gazaas depicted in Figure 1. These countries are shown in red colour. Reports state that the average national percentage of total renewable water resources withdrawn from (MENA) region countries was nearly 338\% in between the years 1998 to 2002 [2]. Climate change and the increasing demand of water resources as a result of population and economic growth have received the serious global concern. However, the increase of water scarcity has consequently limited the progress of MENA societies as it increases poverty and decreases socio-economic life, unemployment and migration. In addition, it is estimated that the increase in average air temperature in MENA is projected to be higher than the projected increase in average global air temperature, which will mean that rainfall pattern will be affected in the region and surface water will dry up, affecting the overall water availability [3].

Despite the growing population, water resources which were used in the agricultural sectors in the MENA region countries' economies produced little wealth,

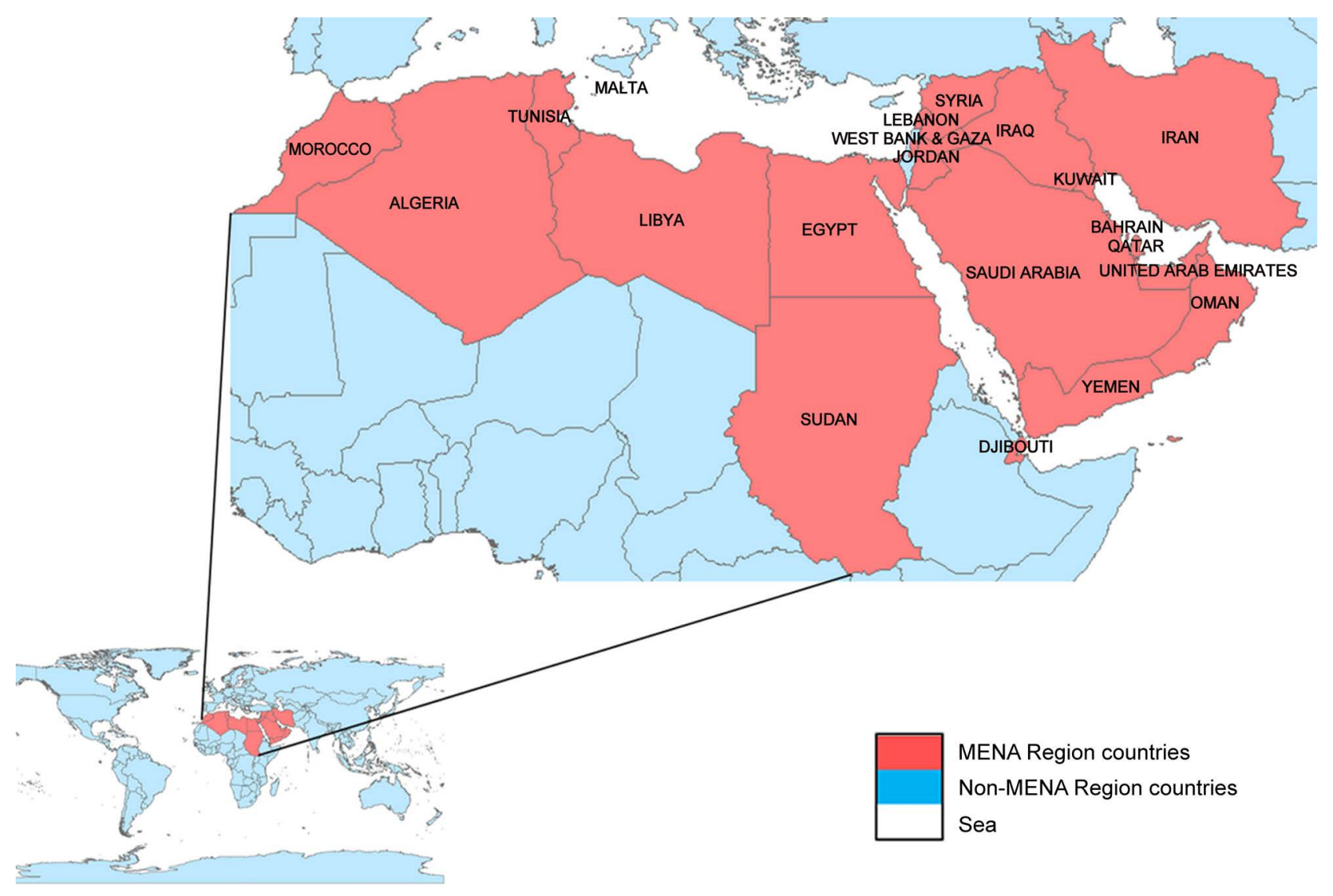

Figure 1. MENA region countries [4]. 
contributing approximately 8 percent of the GDP on average in 2005 [5]. Again, because of lack of wealth, many people in the region are dependent on agriculture which comprises 29 percent of labour in rural areas [6]. In many of the MENA region countries, the agricultural sector's contribution to GDP is relatively low and even lower than countries whose main export is oil. The agriculture sector depends massively on water for farming activities which consume about $80 \%$ of the available water resource [7]. Unsustainable use of water in irrigated agriculture in this region has led to the depletion of the renewable water resources. This is because of the inefficient use of available water by farmers and in doing so affect the quality of water negatively. The quality of the water is also affected not only by the agriculture sector but also industry and household effluents.

Water scarcity should not only focus on water resources that are not enough for human consumption but theavailability of quality water is also important [8]. For example, water resources that are contaminated cannot be used for drinking, bathing, and cooking, industrial production and agriculture purposes. It affects human health and eventually causes ecosystems to disappear. It is obvious that MENA region countries are facing environmental water scarcity and it is hindering sustainable development. Despite the quality of research on water scarcity in the MENA region countries, it is also important to give more attention to the environmental water scarcity [9] [10] [11] [12] [13]. Hence, the contribution to water scarcity does not include merely socio-economic factors and possible linkages associated with climate change. Although this paper is not examining the monetary cost of environmental degradation on water scarcity, it will contribute to the creation of environmental awareness towards sustainable development. The main goal of this article is to provide some insight on environmental water scarcity in the world particularly MENA region countries. We examine activities that put stress on water resource and highlight on why the implementation of this particular term (Environmental water scarcity) is hindering sustainable development.

\section{Water Scarcity Concept}

Water scarcity occurs when there is inadequate water to satisfy the demand. Regions where water resources are abundant but demand exceeds the supply capacity of the natural system also experience water scarcity. Water scarcity can emerge or worsen when there is continues water imbalances, the groundwater is degraded affecting water quality, conflicts within nations and across nations over shared water resources and climate change [14]. Although there is an excessive emphasis placed on climate change as the major contributor of water scarcity in water stress countries, high population density, tourist inflow and human activities such as intensive agriculture and industries that take vast amount of water for production also contribute to water scarcity.

The actual renewable fresh water resources in the MENA region countries are the lowest in the world and agriculture dominates the demand for water. Water scarcity mostly affects the people living in the rural area in the MENA region 
countries. This is because they tend to use more water for agriculture. The farmers have no any other option than relocate to urban areas to compete for the quantity of water available. It is indicated that water scarcity affects more rural dwellers than any other place in the region [15] [16] [17].

Water scarcity is an issue of poverty across the world. Countries or regions which are currently experiencing water scarcity such as Africa, the Middle East and China lack the proper water infrastructure as well as proper sanitation for clean water supply. As previously indicated, the rural farmers are mostly affected by water scarcity, therefore, in order to sustain their lives and secure their livelihoods, fair and safe access to water, good infrastructure development and corruption free water management institutions and among others must be in place. As stated by FAO that, for poor people, water scarcity is how institutions function and how transparency and equity are guaranteed in decisions that affect lives. Again, for poor people, it is about choices on infrastructure development and the way they are managed [14]. In the presence of declining water quality [18], climate change can have a big impact. For example, in Israel, the quality of supplied water resources varies from low salinity water at $10 \mathrm{mg} / \mathrm{l}$ of chlorides from upper Jordan River, $200 \mathrm{mg} / \mathrm{l}$ from Kinneret, and more than $500 \mathrm{mg} / \mathrm{l}$ from ground water sources in the south [19]. Another serious land use activity that affects water quality is irrigation. Inefficient irrigation increase salinization in the soil [20]. The increase of saline in groundwater affects organisms that live in the soil and affect plant growth.

\section{Water Scarcity Definition}

There is no universally accepted definition of water scarcity and it is a complex socio-ecological issue. At this point, the authors relied on the definition of FAO who defines scarcity as "needs to be understood as a relative concept", i.e., an imbalance between "supply" and "demand" that varies according to local conditions as well as "fundamentally dynamic". This implies that demand has to exceed supply and both can change over time, but water scarcity would still occur if only demand rises but supply stays stable or even increases but at lower rates than demand. The water scarcity issues in water-stressed regions around the globe can be minimized when the adequate measures are put in place to address the problem.

Additionally, FAO describes several dimensions through which water scarcity can emerge, of which the following are chosen for the discussions. First, in line with the definition of water scarcity by FAO, the availability and quality of water resources and the continuous demand by users can be attributed to physical water shortage. Water scarcity can be due to physical water scarcity and it can also be described in relation to the access to water services. In terms of water delivery, institutions responsible are unable to implement water policy to ensure that water reaches the user at a reliable and quality manner. Water scarcity can occur due to a lack of adequate infrastructure and funds to effectively and efficiently manage water resources in the water-stressed regions [14]. Taking into 
accounts, the definition of water scarcity and droughts we propose the inclusion of environmental water scarcity in our discussion part with a sense of urgency in the sustainable Development Goals (SDGs) of the 2030-Agenda for Sustainable Development.

Water resources are not enough for human consumption despite the availability of water. In the attempt to achieve the MDG targets, international efforts and bodies are supporting developing countries to have continued access to safe drinking water and basic sanitation by 2015. This is because several developing countries are facing water and sanitation infrastructural problems, particularly rural areas. In the 2030 agenda for sustainable development, the targets under Goal 6 are interdependent and address major challenges regarding water-related issues [21]. For examples, there exist more connections between goal 6 and other goals such as sustainable food production systems 2.4, decoupling economic growth from environmental degradation 8.4, sustainable infrastructure and industry 9.4, reducing the per capita environmental impact of cities 11.6, and sustainable consumption and production 12.1 - 12.8 [22].

It is important to know that, in many instances, the specific goal of the SDG 6 is to ensure availability and sustainable management of water and sanitation for all [21]. Under the goal, the SDG areas of concern are targeting universal access to safe, adequate, affordable drinking water and providing good sanitation and hygiene.The SDGs targets go beyond targeting hygiene and access to suitable water to addressing key challenge such as increasing water-use efficiency, improving water quality by reducing pollution by agriculture, industries, household waste into water bodies. In addition, the measures of water quality associated with the goal are in line with recycling and reuse of wastewater from household, industry, agriculture and runoff [16]. Other important areas such as the strengthening of trans boundary cooperation, managing available water resources through effective implementation of integrated water resources management [23] [24]. The protection of water-related water ecosystems, international cooperation, capacity-building support, woman empowerment, supporting and strengthening stake holders and stakeholders participation in improving water and sanitation management was obvious in several recommendations levelled by several scholars [1] [25] [26].

Figure 2 shows the proportion of renewable water resources that have already been withdrawn around the globe. It further shows that the MENA region countries and Central Asia are at significant risk of water scarcity, as most countries in both regions have withdrawn more than $28.73 \%$ of their water resources. Table 1 also shows the proportion of renewable water resources that have already been withdrawn based on the water volume and percentage water withdrawal by agriculture, domestic and industries over total renewable water resources in each year. The higher the water volume and percentage withdrawn the higher thestress on the water supply and demand of water was rising in the agriculture field especially for irrigation (Table 1). Irrigation farming increases due to the implementation of agricultural policies in some MENA region countries aimed at 


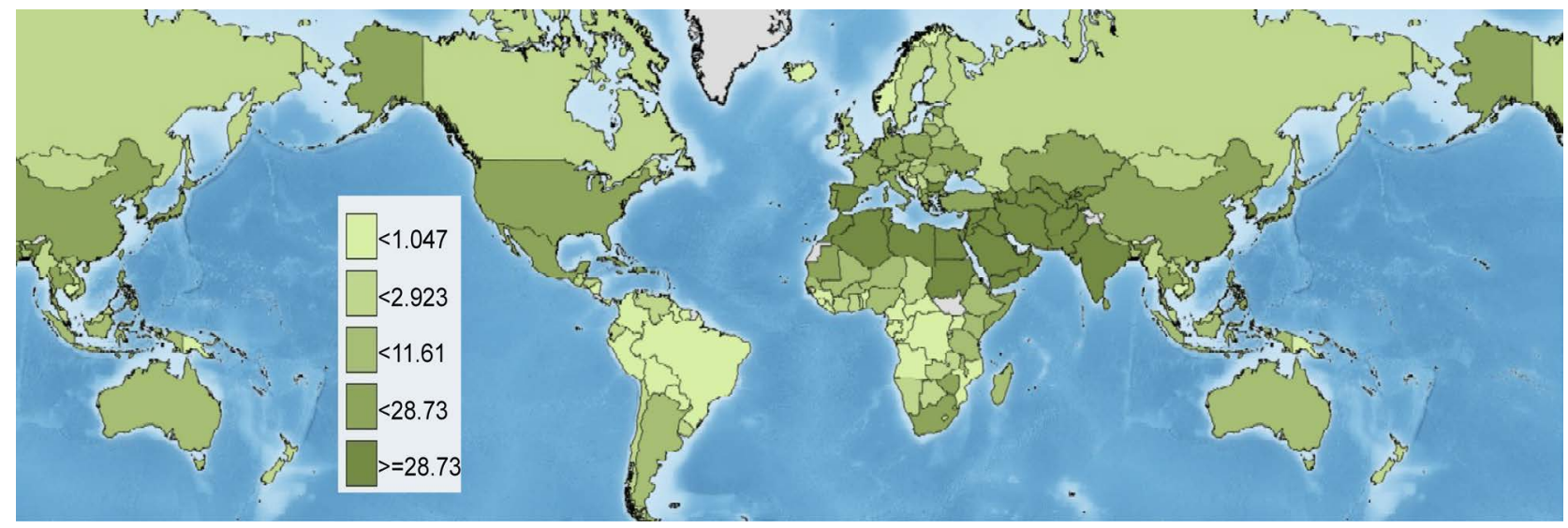

Figure 2. Proportion of renewable water resources withdrawn [27].

Table 1. Water withdrawal by sector.

\begin{tabular}{|c|c|c|c|c|c|c|}
\hline \multirow[b]{2}{*}{ Country } & \multicolumn{4}{|c|}{ Water withdrawal volume $\left(\mathrm{km}^{2} /\right.$ year $)$ per sector } & \multicolumn{2}{|c|}{ Percentage water withdrawal per sector } \\
\hline & Agriculture & Domestic & Industry & Agriculture & Domestic & Industry \\
\hline Algeria & 3.9 & 1.3 & 0.8 & 64.9 & 21.9 & 13.2 \\
\hline Bahrain & 0.2 & 0.1 & 0 & 56.7 & 40 & 3.3 \\
\hline Djibouti & 0 & 0 & 0 & 15.8 & 84.2 & 0 \\
\hline Egypt & 59 & 5.3 & 4 & 86.4 & 7.8 & 5.9 \\
\hline Iran & 66.2 & 5 & 1.7 & 0.9 & 6.8 & 2.3 \\
\hline Iraq & 39.4 & 1.4 & 2 & 92.2 & 3.2 & 4.6 \\
\hline Jordan & 0.8 & 0.2 & 0 & 75.3 & 20.8 & 4 \\
\hline Kuwait & 0.2 & 0.2 & 0 & 52.3 & 45.5 & 2.3 \\
\hline Lebanon & 0.9 & 0.5 & 0 & 66.7 & 32.6 & 0.7 \\
\hline Libya & 3.5 & 0.6 & 0.1 & 83 & 14.1 & 2.9 \\
\hline Morocco & 11 & 1.2 & 0.4 & 87.4 & 9.8 & 2.9 \\
\hline Oman & 1.2 & 0.1 & 0 & 90.4 & 7.4 & 2.2 \\
\hline Qatar & 0.2 & 0.1 & 0 & 72.4 & 24.1 & 3.1 \\
\hline Saudi Arabia & 17.5 & 2.1 & 0.6 & 86.5 & 10.4 & 3.5 \\
\hline Syria & 18.9 & 0.7 & 0.4 & 94.9 & 3.3 & 1.8 \\
\hline Tunisia & 2.2 & 0.4 & 0.1 & 82 & 13.8 & 4.2 \\
\hline United Arabia Emirates & 1.6 & 0.5 & 0.2 & 68.3 & 23 & 8.7 \\
\hline West Bank and Gaza & 0.2 & 0.1 & 0 & 53 & 45 & 2 \\
\hline Yemen & 6.3 & 0.3 & 0 & 95.3 & 4.1 & 0.6 \\
\hline MENA average & 74.4 & 22 & 3.6 & 12.3 & 1.1 & 0.5 \\
\hline
\end{tabular}

Source: AQUASTAT 1998-2002 cited from World Bank, Making the Most of Scarcity: Accountability for Better Water Management Results in the Middle East and North Africa; World Bank Publications, 2007. Available data includes only 19 countries from the MENA region. 
achieving food security [28] [29]. With regards to the MENA region countries agriculture still constituted the highest withdrawal of (74.4\%) of water, followed by domestic consumption (22\%) and finally industry (3.6\%) in Table 1 . The legend on the map shows freshwater withdrawals as $\%$ of total renewable water resources.

\section{Discussion of Environmental Issues in MENA Regions}

To understand some of the pertinent issues in the MENA region countries in relation to climate change impacts, water scarcity and socio-economic activities, the following discussion should be viewed in a conceptual manner. First climate change itself will be examined, followed by climate change and water scarcity, environmental Stress and water scarcity, water pollution control and policy implementation and natural disaster and migration.

\section{Climate Changes and Water Scarcity}

The consequences of water scarcity in the arid and semiarid regions cannot be over emphasized. These areas are affected by droughts and wide climate variability, and the challenges are expected to worsen as the population and economic development increases. As indicated earlier in Figure 2, MENA region countries are more affected by climate change since they are located in the most water strained world region. For instance, all the MENA region countries located on the coast of the Mediterranean experience coastal aquifers contamination through seawater intrusion due to an increase in the sea levels in low-lying areas [30]. Saltwater infiltrates into the soil causing high salinity. The fresh water lens is affected because the use groundwater from the lenses is unsustainable. The freshwater lens is an important part of the ecological system that is particularly susceptible to pollution. In this regard, it appears that climate change does not only decrease the quantity of fresh water but the quality of groundwater might be negatively affected. On contrary, [31] indicated that not only the quality of groundwater that will be affected but the whole landscape making it difficult for human and other living organisms to live. Egypt had a share of water per capita of 860 $\mathrm{m}^{3} /$ year in 2003 and expected to decrease to $582 \mathrm{~m}^{3} /$ year by the year 2025 [32]. This projection will imply that food security will be at risk [33].

\section{Linking Environmental Stress to Water Scarcity}

The water quality-induced water scarcity has been given less attention in the developing countries where water-related problems are a major setback to socioeconomic development. Although more than one in every six people in the world affected by water stress is living in developing countries, the rapid growth of economies and change of lifestyles, waste water disposal, agricultural runoff containing hazardous substance have all contributed immensely to surface and groundwater pollution, limiting the use of water [34]. EPA [35] also buttressed the fact that surface runoff containing hazardous substances or high concentration such as sediments, nutrients, and pesticides from agricultural fields into water bodies 
contribute to the major cause of non point-source pollution in the United States.

In the MENA region countries, discussion on the effects of water scarcity is common because water quality is adversely affected by industrial, agricultural, transport, energy, human settlement and domestic effluent. Therefore, the terms "Environmental Water scarcity" is an important factor because it includes activities that put stress on water resource. This term is not new. Pfister et al. [36] did not use the term directly but used it as a means to measure potential environmental damages of water use for three areas: human health, ecosystem quality, and resources whiles Lebanon State of the Environment Report in 2001 described the term as the potential environmental stresses on water resources. The economic activities related to water scarcity is not only to decrease the available water but also degrade the quality.

Naturally, mineral from the surface of the earth and minerals can flow naturally into the underground water impairing the taste and limiting its use. By human action, oil spillage, leakage, improper disposal of chemical waste on the land surface by human actions can result in runoff that contaminates underground water, aquifers, streams and lakes [37]. Studies had shown that the effects of change in land use are likely to impact on the quality of underground water [38] [39]. This is because the reduction of the vegetation exposes the land to the harsh environmental conditions and prevents vegetation cover to control surface runoff. Consequently, groundwater infiltration increases and sediments fill up dams, rivers and lakes.

Again, the consequences of eutrophication resulted from nitrogen related water pollution have been conducted [40]. An excessive amount of nitrogen and phosphorous in lakes and streams can lead to algal blooms and excessive growth of aquatic plants which will significantly increase algae. The eutrophication process can harm water quality, food resources and result in serious environmental and human health issues. For example, Wan et al. [41] found out that nitrogenrelated gray water footprint was caused by pollution from economic activities.

Many of the African and MENA region countries share common unsustainable use of natural resources. The changes of land cover, land use and farming methods affect water resources negatively and rural community where water is a problem. Although much of the Middle East region is characterised by a Mediterranean climate, the unsustainable management of the land and crops in the region can lead to degradation of the available arable land [42]. Farmers in the water-stressed regions have been relying increasingly on groundwater for agriculture, thus causing water pollution, rapid depletion of aquifers and decline in ground water table. Nonetheless, though industries use a lot of water in their production daily and at the same time release a large amount of wastewater into the environment. The hazardous wastewater flows into the nearby lake, streams and underground water. Qin [43] confirmed that because of excessive pollution, southern parts of China which are known for their abundant resources are facing water shortage. Despite the limited data for quantifying pollution load in the MENA region countries, the environmental Stress on the water resources is evi- 
dent and should be highlighted.

\section{Water Pollution Control and Policy Implementation}

Establishing quality control policies and enforcing it has generally become a problem in MENA region countries. This is due to several factors, hindering sustainable development. Though there has been water legislation in some of the countries, specific emphasis is not given to quality control and often lack proper enforcement. For example, in Syria, the government is developing a National Environmental Action Plan (NEAP) yet Syria and Lebanonlack basic environmental information because of information-hoarding by institutes and monitoring agencies are weak in infrastructure which makes their daily work difficult [44] [45]. In Lebanon, laws and regulations related to the water sector are poorly implemented and enforced. Research conducted by Farajalla [46] found out that weak implementation and enforcement of water-related policies are attributed to some challenges such as, poor coordination among relevant ministries and departments. There is no legal basis for enforcement in the existing law, limited staff and fund to manage the water sector, besides the lack of accountability and corruption, undermining the integrity of the monitoring agencies. All of the above are setbacks to sustainable development in MENA.

In the MENA regions, the World Bank found out that the ineffective management of water resource is due to poor monitoring, accountability by government or authorities responsible for water resource management and industries are [47]. Another argument which undermines the implementation of water quality control is the improper and poor performance of many water utilities which are mostly attributed to funding and fragmented policies. There exist unclear responsibilities for departments responsible for the operation of water management, creating problems like conflict and political interference.

Currently, MENA region countries, if not all has invested in water infrastructure with or without foreign support. Thelack of maintenance, poor planning and coordination among water sectors has made most of them unable to perform for the purpose for which there were designed [48].

Corruption and the lack of political trust are some of the key hurdles to enforce environmental regulations and laws, particularly water governance in developing countries, and MENA region countries are not an exception. In MENA region countries, UNDP [49] had it that the monocratic regimes trigger corruption, allowing and politically well-connected businessmen to excel at the expense of the poor people. The result is that non-privilege one; particularly the poor people lose trust in the leadership, and consequently decrease in participation in socio-economic activities in their respective regions. Again, the poor people has no choice but to practice corruption by paying bribes to corrupt personnel for digging illegal wells. In doing that they contaminate the underground water because monitoring of such activities are missing. The existence of corruption and political interference has resulted in mistrust and suspicion among poor people especially when some basic national policies programs and projects are located 
in the urban areas [50]. Meanwhile, in Jordan, Algeria, Lebanon, Morocco, Palestine, Tunisia and Yemen, the lack of public awareness of the health implication of contaminated water is also missing [51] [52].

\section{Natural Disasters and Migration}

The MENA region countries have been affected by recent conflict, crisis and natural disasters that are exacerbated by climate change. Climate change intensifies migration through natural hazards, water scarcity, and conflicts over natural resources and produces environmental effects which make it difficult for people to cope with life where they are [53]. An increase in the number of reported natural disasters cases and affected people are observed in the Mediterranean region and other riparian countries in the MENA [54]. In other non-MENA region countries, the tsunamis, hurricanes and earthquakes that occurred in Asia and the Americas in 2004 and 2005, and Haiti earthquake in 2010 displaced a quite number of people has shown the need to devote much attention to affected people. A high number of affected people are forced to migrate to another place of residence as a result of the aforementioned disasters [55] [56]. Research shows that the affected people are discriminated in terms of economic, social, and cultural rights.

The major consequence of natural disaster is that people affected must relocate. In 2014, for example, over 19.3 million people were displaced by waterrelated disasters across 100 countries and 17.5 million people by weather-related hazards [57]. Again, because of the adverse impact of climate change, an average of 22.5 million people has been displaced each in the last seven years which is equivalent to 62,000 people every day [57]. The affected people, especially farmers, move to the urban cities, thereby increasing the population growth rate in the city. Obviously, the overwhelming increase in displaced people across the globe and over the years is related to weather conditions and climate-related disasters such as storms, droughts and floods [55].

\section{Adoption Strategies for Water Use in MENA Regions}

Alarmingly, water resources in the Arab countries are not enough for use. The reason being that approximately $1 \%$ of the world's renewable fresh water are recorded in these countries and almost $2 / 3$ of the water resources are originated from non-Arab countries [58]. Among the challenges facing MENA region countries such as climate change, water scarcity and related problems, assorted measures have been mentioned to address the worrying menace. The MENA region countries need to intensify the strategies according to National Water Resources Plan (NWRP). Though some of the measures are undertaken by the government, most of them are supported by organisations, agencies and foundations in the area of training, expertise and financial support for water project. Thesemeasures provide increase environmental health outcomes and help improve the MENA region countries virtual water import balance. There are a lot of water projects going on in the MENA-Regions such as the World Bank supported pro- 
jects and these projects have proven to be very effective.

First, the World Bank (WB) project restored the basic water supply and sanitation services in Iraq. In 2009, the WB projecthas helped to significantly reduce the number of Iraqis in Baghdad who did not have access to clean water. Second, Taiz in Yemen investment in flood control structures has led to the reduction of the number of deaths per year, an average of six people per year to zero, an increase in land. Additionally, property and infrastructure damages in Taiz because of the flood were reduced which also cut down the cost of maintaining public service particularly water and sewer networks. Finally, Egypt is improving irrigated agriculture management in terms of water use efficiency and service and that has led to the sustained improvement of civil works contracts and institutional reform in 2015. In the irrigation sector, the progress made regarding devolution of irrigation management responsibilities from a centrally managed system to a participatory and community-based water user organisations (WUOs) is encouraging.As noted in (Table 1), some of these coping mechanisms are not peculiar to MENA region countries but are also found elsewhere where there is water stress [1] [25] [26]. Table 2 shows some additional adaptive measures that are relevant for MENA region countries in two distinct areas such as agriculture sectors and policy makers.

\section{Conclusions}

The pertinent issues in the MENA region countries in relation to climate change impact and water scarcity are understood. This article further discussed some important activities that put stress on water resource or led to environmental water

Table 2. Additional adaptation measures.

For agricultural sectors

- Cultivation of high-value crops

- Cultivation of drought resistance seed and

- Cultivation of salt resistance seeds

- diversification of agricultural

- Groundwater recharge

- Reduction of losses in irrigation networks

- Non-conventional water use

- Improvement of irrigation efficiency virtual water

- Maintaining water distribution infrastructure
- Change in cropping patterns or system

- Small-scale farming fostering ecological methods

- Desert land reclamation

- Sea-based and reservoir-based aquaculture

- Desalinization

- Effective water pricing

- Rainfall harvesting

- Reducing agricultural carbon footprint

For policy makers

- Governments support to local knowledge and modern practices

- Providing good sanitation and hygiene

- Monitoring of diffuse (agricultural) and point (industrial and household) pollution

- Building protective coastal infrastructures

- Implementation of the integrated water resources management (IWRM) approach

- Increase in resource efficiency

- Creation of incentives to reduce climate change

- Local wastewater purification and treatments
- Effective collaboration with private sector, NGOs etc.

- Subsidising new technologies that conserve water

- Increase attention on management of food reserves

- Investing in agricultural facilities

- Water pollution controls policies

- Strengthening of regional and cross-border and local cooperation

- Protection of the ecosystems

- Stakeholders and political support

- Capacity building of stakeholders

- Grey water and wastewater recycling 
scarcity. However, this article also provided brief argumentations that lacks of implementation of environmental water scarcity measures are hindering sustainable development, particularly the MENA region countries. Some important adaptation measures regarding water scarcity in MENA region countries were identified. The adaptation measures are dependent on the feasibility or technical capability of the country to adapt. The governments should support adaptive measures at the local level to address water scarcity problem and ensure such measure target populations that are likely to feel the impacts.

Lastly, the issue of water scarcity is receiving increased attention from policymakers in the midst of climate change. FAO has produced agriculture water withdrawal maps showing areas with excessive water withdrawn for the purposes of irrigated agriculture, however, there is no map describing and showing areas that are experiencing environmental water scarcity. The current maps available online help to identify water stress areas and depict the distribution of water withdrawn for agriculture. But will the current map help us to see the polluted areas, or do we need a new map to show polluted hotspot areas that trigger environmental water scarcity? In the light of future research work, we recommend that a new map is relevant to show polluted areas, particularly MENA region.

\section{Acknowledgements}

The authors would like to acknowledge Michel Venne, Brandenburgische Technische Universität Cottbus-Senftenberg, who read the entire manuscript. The authors are grateful to the anonymous reviewers for their comments and suggestions that shaped the work.

\section{Author Contributions}

The authors contributed immensely towards the preparation and interpretation of this paper and approved the final version of the manuscript.

\section{Conflicts of Interest}

The authors declare no conflict of interest.

\section{References}

[1] FAO (2011) FAO-Adapt-FAO’s Framework Programme on Climate Change Adaptation.

http://www.fao.org/climatechange/27594-03ecd7bd225b93086e7dca3944de64307.pd $\underline{\mathrm{f}}$

[2] Farajallah, N. (2012) The Middle East and North Africa's Water Resources in a Changing Climate. Heinrich Boell Foundation, Berlin.

https://www.boell.de/en/2012/10/31/middle-east-and-north-africas-water-resources -changing-climate

[3] Ölund Wingqvist, G. and Drakenberg, O. (2010) Environmental and Climate Change Policy Brief-MENA. Department of Economics, University of Gothenburg, Gothenburg, $12 \mathrm{p}$.

[4] Ahmed, G. (2016) Center on Globalization, Governance \& Competitiveness: Duke 
University MINERVA Annual Meeting. Washington DC.

[5] Gregoire, G. (2007) Climate Change Adaptation in the Water Sector in the Middle East and North Africa: A Review of Main Issues. 25 p.

[6] Tropp, H. and Jägerskog, A. (2006) Water Scarcity Challenges in the Middle East and North Africa (MENA). Human Development Reports.

http://hdr.undp.org/en/content/water-scarcity-challenges-middle-east-and-north-af rica-mena

[7] Shetty, S. (2006) Water, Food Security and Agricultural Policy in the Middle East and North Africa Region. World Bank, Washington DC.

[8] Châtel, F., Holst-Warhaft, G. and Steenhuis, T.S. (2014) Water Scarcity, Security and Democracy: A Mediterranean Mosaic. Athens, Greece, and Ithaca, 178 p.

[9] Pedraza, L.E. and Heinrich, M. (2016) Water Scarcity: Cooperation or Conflict in the Middle East and North Africa?

http://www.foreignpolicyjournal.com/2016/09/02/water-scarcity-cooperation-or-co nflict-in-the-middle-east-and-north-africa/

[10] Zafar, S. (2014) Water Scarcity in MENA. EcoMENA. http://www.ecomena.org/water-scarcity-in-mena/

[11] Zyadin, A. (2013) Water Shortage in MENA Region: An Interdisciplinary Overview and a Suite of Practical Solutions. Journal of Water Resource and Protection, 5, 4958. https://doi.org/10.4236/jwarp.2013.54a008

[12] Droogers, P., Immerzeel, W.W., Terink, W., Hoogeveen, J., Bierkens, M.F.P., van Beek, L.P.H., et al. (2012) Water Resources Trends in Middle East and North Africa towards 2050. Hydrology and Earth System Sciences, 16, 3101-3114. https://doi.org/10.5194/hess-16-3101-2012

[13] Jemmali, H. and Sullivan, C.A. (2012) Multidimensional Analysis of Water Poverty in MENA Region: An Empirical Comparison with Physical Indicators. Social Indicators Research, 115, 253-277. https://doi.org/10.1007/s11205-012-0218-2

[14] FAO (2015) FAO Water Unit. Water News: Water Scarcity. http://www.fao.org/nr/water/topics_scarcity.html

[15] UN-Water (2007) Coping with Water Scarcity: Challenge of the Twenty-First Century.

[16] Corcoran, E.C., Nellemann, E., Baker, R., Bos, D., Osborn, H. and Savelli (2010) Sick Water? The Central Role of Wastewater Management in Sustainable Development. A Rapid Response Assessment. United Nations Environment Programme, UN-HABITAT, GRID-Arendal. UNEP and UN-HABITAT.

[17] UNDP (2013) Water Governance in the Arab Region: Managing Scarcity and Securing the Future. New York.

[18] Postel, S.L., Daily, G.C. and Ehrlich, P.R. (1996) Human Appropriation of Renewable Fresh Water. Science, 271, 785-788.

https://doi.org/10.1126/science.271.5250.785

[19] Ministry of Foreign Affairs (2017) Israel's Chronic Water Problem. Israel.

[20] Hinrichsen, D., Robey, B. and Upadhyay, U. (1997) Solutions for a Water-Short World. Report No. 14, Johns Hopkins School of Public Health, Population Information Program, Baltimore.

[21] UN (2015) Transforming Our World: The 2030 Agenda for Sustainable Development. https://sustainabledevelopment.un.org/post2015/transformingourworld

[22] Horayangkura, P. (2014) Legal Document. Assumption University Law Journal, 5, 114-132. 
http://its-3.au.edu/open_journal/index.php/LawJournal/article/viewFile/993/900

[23] Rahaman, M.M. and Varis, O. (2005) Integrated Water Resources Management: Evolution, Prospects and Future Challenges. Sustainability. Science, Practice, \& Policy, 1, 15-21.

[24] Kalenikova, I. (2009) The Integrated Water Basin Approach for the Sustainable Water Management in International and Regional Legislation. LL.M Laster Thesis, Haskoli Island.

[25] Bates, B. and Kundzewicz, Z.W. (2008) Climate Change and Water. Technical Paper of the Intergovernmental Panel on Climate Change, IPCC Secretariat, Geneva, 210 p.

[26] UNFCCC (2007) Climate Change: Impacts, Vulnerabilities and Adaptation in Developing Countries. Climate Change Secretariat (UNFCCC), Bonn, 68 p.

[27] FAO (2017) AQUASTAT-FAO’s Information System for Water and Agriculture.

[28] Wakil, M. (1993) Analysis of Future Water Needs for Different Sectors in Syria. Water International, 18, 18-22. https://doi.org/10.1080/02508069308686144

[29] Figueres, C., Rockstrom, J. and Tortajada, C. (2012) Rethinking Water Management: Innovative Approaches to Contemporary Issues. Routledge, Abingdon-onThames.

[30] Sivakumar, M.V.K., Lal, R., Selvaraju, R. and Hamdan, I. (2013) Climate Change and Food Security in West Asia and North Africa. Springer Science \& Business Media, Berlin, 3-26. https://doi.org/10.1007/978-94-007-6751-5

[31] El-Quosy, D.E. (2009) "Fresh Water", in Arab Environment: Climate ChangeImpact of Climate Change on Arab Countries. Arab Forum for Environment and Development, Beruit, 75-86.

[32] UN-HABITAT (2010) The State of African Cities 2010: Governance, Inequality and Urban Land Markets. UN-HABITAT, Nairobi.

[33] Fawaz, M.M. and Soliman, S.A. (2016) The Potential Scenarios of the Impacts of Climate Change on Egyptian Resources and Agricultural Plant Production. Open Journal of Applied Sciences, 6, 270-286. https://doi.org/10.4236/ojapps.2016.64027

[34] UNEP (2006) Human Development Report 2006: Beyond Scarcity-Power, Poverty and the Global Water Crisis. Palgrave Macmillan, Basingstoke.

[35] EPA (2002) National Management Measures to Control Nonpoint Source Pollution from Agriculture. Office of Wetlands, Oceans, and Watersheds, EPA, Washington DC.

[36] Pfister, S., Koehler, A. and Hellweg, S. (2009) Assessing the Environmental Impacts of Freshwater Consumption in LCA. Environmental Science \& Technology, 43, 4098-4104. https://doi.org/10.1021/es802423e

[37] Water Encyclopedia (2016) Land Use and Water Quality-River, Effects, Important, Salt, Types, System, Plants, Source, Effect, Oxygen, Human.

[38] Putri, L.S.E., Kustanti, N. and Yunita, E. (2013) Effect of Land Use on Ground Water Quality (a Case Study from Ciracas Sub District, East Jakarta, Indonesia). International Journal of Bioscience, Biochemistry and Bioinformatics, 3, 33. https://doi.org/10.7763/IJBBB.2013.V3.158

[39] Trojan, M.D. (2003) Effects of Land Use on Ground Water Quality in the Anoka Sand Plain Aquifer of Minnesota.

[40] Mekonnen, M.M. and Hoekstra, A.Y. (2015) Global Gray Water Footprint and Water Pollution Levels Related to Anthropogenic Nitrogen Loads to Fresh Water. Environmental Science \& Technology, 49, 12860-12868. 
https://doi.org/10.1021/acs.est.5b03191

[41] Wan, L., Cai, W., Jiang, Y. and Wang, C. (2016) Impacts on Quality-Induced Water Scarcity: Drivers of Nitrogen-Related Water Pollution Transfer under Globalization from 1995 to 2009. Environmental Research Letters, 11, Article ID: 074017. https://doi.org/10.1088/1748-9326/11/7/074017

[42] EU Water Initiative (2006) Water Scarcity Management in the Context of WFD. Water Scarcity Drafting Group, 121 p.

[43] Qin, C. (2011) Mitigating China's Water Scarcity and Pollution: Environmental and Economic Accounting, Modelling and Policy Analysis. ITC.

[44] METAP (2011) Water Quality Management. Syria.

[45] Studies and Integration Consulting (2009) Institutional Framework and Decision Making Practices for Water Management in Syria. INECO, Syria.

[46] Farajalla, N., El Hajj, R., Kerkezian, S., Farhat, Z. and Matta, M. (2015) The Way Forward to Safeguard Water in Lebanon: National Water Integrity Risk Assessment. American University of Beirut, Lebanon.

[47] Glausiusz, J. (2013) Environmental Concerns Reach Fever Pitch over Plan to Link Red Sea to Dead Sea. Journal of Water Resource and Protection, 5, 49-58. https://doi.org/10.1038/nature.2013.12515

[48] Rached, E. and Brooks, D.B. (2010) Water Governance in the Middle East and North Africa: An Unfinished Agenda. International Journal of Water Resources Development, 26, 141-155. https://doi.org/10.1080/07900621003693321

[49] UNDP (2011) Arab Development Challenges Report 2011. http://www.undp.org/content/undp/en/home/librarypage/hdr/arab-development-c hallenges-report-2011.html

[50] Yorke, V. (2013) Politics Matter: Jordan's Path to Water Security Lies through Political Reforms and Regional Cooperation. NCRR Trade Regulation, University of Bern, Bern.

[51] Groundwater Governance (2012) Arab States Region. Amman.

[52] ACWUA and GIZ (2013) Reader-Good Practices Public Awareness Experiences in the MENA Region. ACWUA in Amman, Jordan GIZ in Bonn and Eschborn

[53] Naudé, W. (2008) Conflict, Disasters, and No Jobs. Research Paper No. 2008/85, United Nations University (UNU), Tokyo.

[54] Brauch, P.D.H.G. (2003) Natural Disasters in the Mediterranean (1900-2001): From Disaster Response to Preparedness. In: Brauch, H.G., Liotta, P.H., Marquina, A., Rogers, P.F. and El-Sayed Selim, M., Eds., Security and Environment in the Mediterranean, Springer, Berlin Heidelberg, 863-906. https://doi.org/10.1007/978-3-642-55854-2_53

[55] WB (2014) Turn down the Heat: Confronting the New Climate Normal. World Bank, Washington DC.

[56] Afifi, T., Govil, R., Sakdapolrak, P. and Warner, K. (2012) Climate Change, Vulnerability and Human Mobility: Perspectives of Refugees from the East and Horn of Africa. United Nations University, Institute for Environment and Human Security (UNU-EHS), Tokyo.

[57] IDMC (2015) Global Estimates 2015. People Displaced by Disaster. Châtelaine, Geneva, $109 \mathrm{p}$.

[58] Tobla, M.K. and Saab, N.W. (2009) Arab Environment: Climate Change. Arab Forum for Environment and Development (AFED), Beirut, $181 \mathrm{p}$. 
Submit or recommend next manuscript to SCIRP and we will provide best service for you:

Accepting pre-submission inquiries through Email, Facebook, LinkedIn, Twitter, etc. A wide selection of journals (inclusive of 9 subjects, more than 200 journals)

Providing 24-hour high-quality service

User-friendly online submission system

Fair and swift peer-review system

Efficient typesetting and proofreading procedure

Display of the result of downloads and visits, as well as the number of cited articles Maximum dissemination of your research work

Submit your manuscript at: http://papersubmission.scirp.org/

Or contact jwarp@scirp.org 